\title{
Determination of Stratigraphy-Soil Types-Using Cone Penetration Test in Sedimentary Deposits in North-East of Argentina
}

\author{
Dante René Bosch, Rubén Rafael Sotelo \\ Center of Applied Geosciences, Faculty of Engineering, National University of Northeast, Resistencia, Argentina \\ Email: danterbosch@gmail.com, rubenrsotelo@yahoo.com.ar
}

Received 14 July 2015; accepted 23 August 2015; published 26 August 2015

Copyright (C) 2015 by authors and Scientific Research Publishing Inc.

This work is licensed under the Creative Commons Attribution International License (CC BY). http://creativecommons.org/licenses/by/4.0/

cc) (i) Open Access

\begin{abstract}
One of the main uses of the cone penetration test (CPT) is to determinate the underground stratigraphy identifying the soils types present. Diverse researchers intended to identify the soils in function of results of CPT by means of the use of classification graphics based on empiric correlations. Also, they stand out the necessity to continue getting into these studies and they emphasize that local experiences could differ from the studies carried out. The experience in the NEA region of our country regarding the use of the CPT is recent; it was incorporated by the middle of the $90 \mathrm{~s}$. However, its continuous and systematic use in geotechnical studies makes that today it has a big database enough to verify the application of international correlations to the soils of the region. The objective of the work consists of verifying the application of the method of identification of soils to the sedimentary soils of the NEA, by means of the analysis of tests of CPT made in different points of the states of Chaco and Corrientes. The results of the study reveal that a good agreement exists among the stratigraphy obtained from CPT tests and those obtained by traditional methods. Although the analyzed universe of data is not of great magnitude and it should be enlarged, it is concluded in a preliminary way that for the soils of the region a good correlation exists between the classification chart with base in CPT and the traditional Unified Soil Classification System (USCS).
\end{abstract}

\section{Keywords}

CPT, USCS, Stratigraphy 


\section{Background}

\subsection{Cone Penetration Test-CPT}

The conepenetration test or CPT consists in thedriving a conepieceintothesoil, linked to a load cell which measures, in a continuousway, soilresistance to penetration of theconetip (qc). It also measures simultaneously resistance of lateral friction (fs) that presents the soil when passing a cylinder piece placed immediately over the cone tip. A drawing and a photo of these measuring elements can be observed in Figure 1.

The technique of drive rods on the ground with geotechnical purposes is a very antique practice used at the beginning for soft soils to find the depth of a firm stratum. First versions of this probe were developed in Sweden in 1917 and it consisted of driving a helical tip, by means of static load and byrotation. As known nowadays the CPT with mechanical tip began to be used in Holland in 1934 to evaluate load capacity of driven piles. Later, in 60's, the electric CPT emerged in which resistance of tip (qc) and sleeve friction (fs) are electrically measured through two load cells mounted with "strains gauges". From the beginning this test began to be used as a habitual tool in geotechnical researches in field, as [1] expresses, especially to establish the subsoil profile quickly and economically.

According to [2], the CPT has three main applications: 1) determining subsoil profile and identifying soils types present, 2) interpolating subsoil conditions between control boreholes, and 3) evaluating geotechnical parameters to estimate load capacity and settlements. Identification of soils types will be treated in this work. Determination of geotechnical parameters is made by the use of empirical correlations. Alternatively, direct methods, without previous determination of parameters, are used to estimate load capacity and settlements. Besides these applications that are routine in geotechnical practices, in recent years they began to be employed to determine composition and distribution of pollutants in soils [3].

\subsection{Identification of Type of Soil Using the CPT}

One of the major uses of CPT is to identify the soil profile. With this test, it is posible to obtain better results than others made with conventional methods. Many researchers have proposed to identify soils types as a function of tip resistance (qc) and friction ratio $(\mathrm{Rf}=\mathrm{fs} / \mathrm{qc})$, and for this they proposed the use of graphics or charts in empirical correlations (e.g. [4]-[8]).

These classifications are based on earlier observations made in Holland, which indicated that sand soils tend to produce high tip resistance and low friction ratio, whereas soft clayey soils tend to produce low tip resistance and high friction ratio.

In this sense, studies made using the mechanical CPT were initiated by [4] and continued later by [5]. In Reference [6], he incorporated results of a great number of tests proposing a classification graph as a function of (qc) and (Rf) magnitudes using the mechanical CPT. For the case of electric tip with standardized geometry, [7] proposed a graph whose correlations are based on a great number of results from tests on the West of the United States. Later, based on an expanded database, [8] presented a soil type classification chart that is broadly used at present and reproduced in Figure 2.

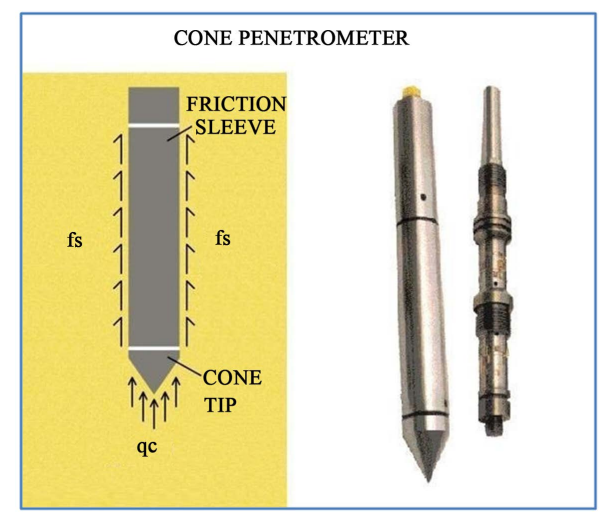

Figure 1. Diagram and inner photo of electric cone tip showing measurement of qc and fs. 


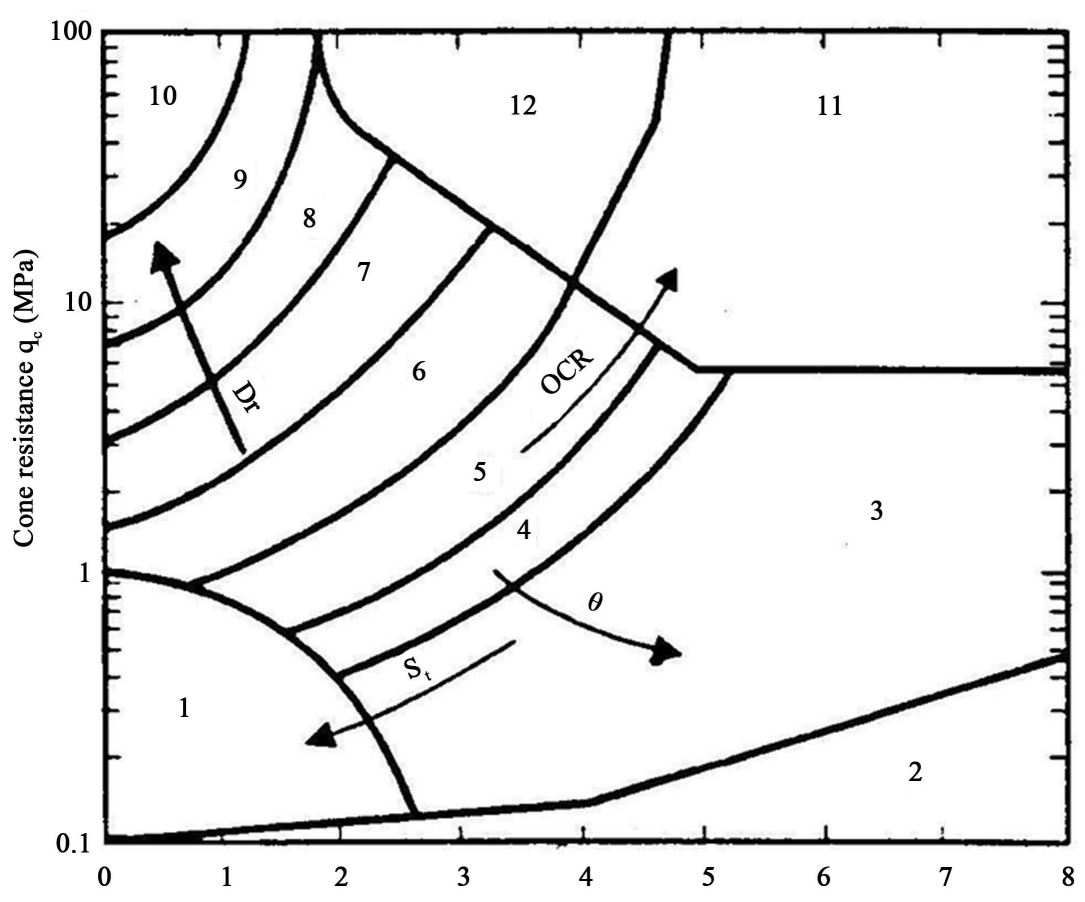

Friction ratio $R f=f s / q c(\%)$

Zone: Soil Behaviour Type:

$\begin{array}{ll}\text { 1. } & \text { Sensitive fine grained } \\ \text { 2. } & \text { Organic material } \\ \text { 3. } & \text { Clay } \\ \text { 4. } & \text { Silty clay to clay }\end{array}$

5. Clayey silt to silty clay

6. Sandy silt to clayey silt

7. Silty sand to sandy silt

8. Sand to silty sand

\begin{abstract}
9. Sand
10. Gravelly sand to sand

11. Very stiff fine grained ${ }^{*}$

12. Sand to clayey sand ${ }^{*}$
\end{abstract}

* Overconsolidated or cemented.

\section{Figure 2. Soil type classification chart proposed by Robertson et al. (1986) [8].}

Reference [2] remarks the necessity of continuing deepening the study of soil identification by the CPT through comparison of obtained results with direct identification in a sampling borehole. He even emphasized that local experiences could differ from studies already made in other places.

Local experience regarding the use of CPT may be said too recent, since it was incorporated in the half of the 90s. However, its continuous and systematic use in geotechnical studies makes that nowadays database can be gotten bigger enough to verify application of international correlations to local soils.

\section{Materials and Methods}

The objective of this work is to verify the application of the identification method of soils proposed by [8] to sedimentary soils in the NEA. Having this objective, a great series of CPT were performed in different points in the states of Chaco and Corrientes.

In the tests standard equipment was used according to instructions given by the ISSMFE (International Society Soil Mechanics and Foundation Engineering) in 1977. Also, test procedures kept Standard ASTM D344186 [9] and Brazilian Standard MB-3406. guidelines [10].

The equipment used has a standardized electric tip (R type), an electronic system of data acquisition and a hydraulic pushing drive system having a capacity of 18 Ton. In Figure 3 a photo and a diagram may be observed used in this work.

Cone penetration tests allowed to obtain a continuous profile of soil properties up to variable depths, registering tip resistance values (qc) and sleeve friction (fs) at intervals of $5 \mathrm{~cm}$. In every case, of CPT were compared to simple boreholes from which samples were extracted and classified in laboratory. 


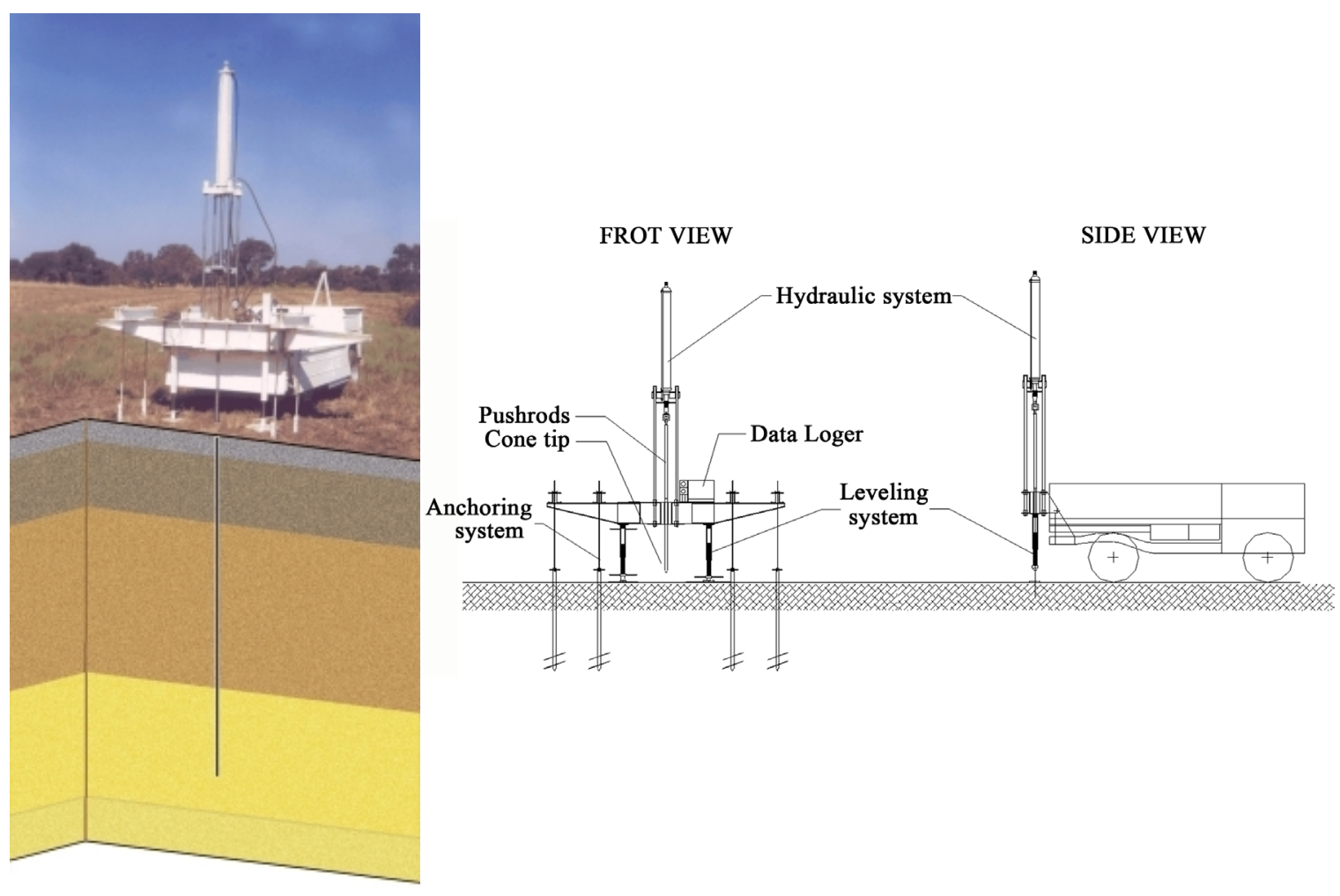

Figure 3. Photo and general diagram of the equipment of CPT tests used for this study.

\section{Maintaining the Integrity of the Specifications}

The template is used to format your paper and style the text. All margins, column widths, line spaces, and text fonts are prescribed; please do not alter them. You may note peculiarities. For example, the head margin in this template measures proportionately more than is customary. This measurement and others are deliberate, using specifications that anticipate your paper as one part of the entire journals, and not as an independent document. Please do not revise any of the current designations.

\section{Obtained Results}

A typical result of analyzed tests is presented in Figure 4. In the first three graphics in this figure, resistance as a function of depth, tip resistance (qc), sleeve friction (fs) and friction ratio (Rf) are represented. The graph on the right represents the soil type as a result of employing [8] classification chart. It may be observed the high degree of detail obtained in the subsoil stratigraphy. Finally, on the right side the stratigraphy of a subsoil obtained by sample borehole was placed.

Figure 5 shows soils types according classification given by the CPT using [8] chart, and soils types obtained from samples at the same depth using the USCS (Unified Soil Classification System). Over hundred per cent of samples belonging to a determinate type of soil according the CPT, sizes of circles represents percentage of results of a determinate kind of soil according USCS. Thus, for example for type 3 according CPT (clay) exists a $65 \%$ of samples which classified as $\mathrm{CH}$ and a $35 \%$ that classified as CL. The quantity of data represented in Figure 5 was ninety-six (96).

\section{Conclusions}

1) In all analyzed cases, a good agreement was found between stratigraphy of soil type obtained from CPT and that obtained from sample boreholes.

2) With the CPT, more detailed subsoil stratigraphy can be obtained, because this test allows identifying small layers with different kinds of soils. 
CONE PENETRATIONT TEST - CPT
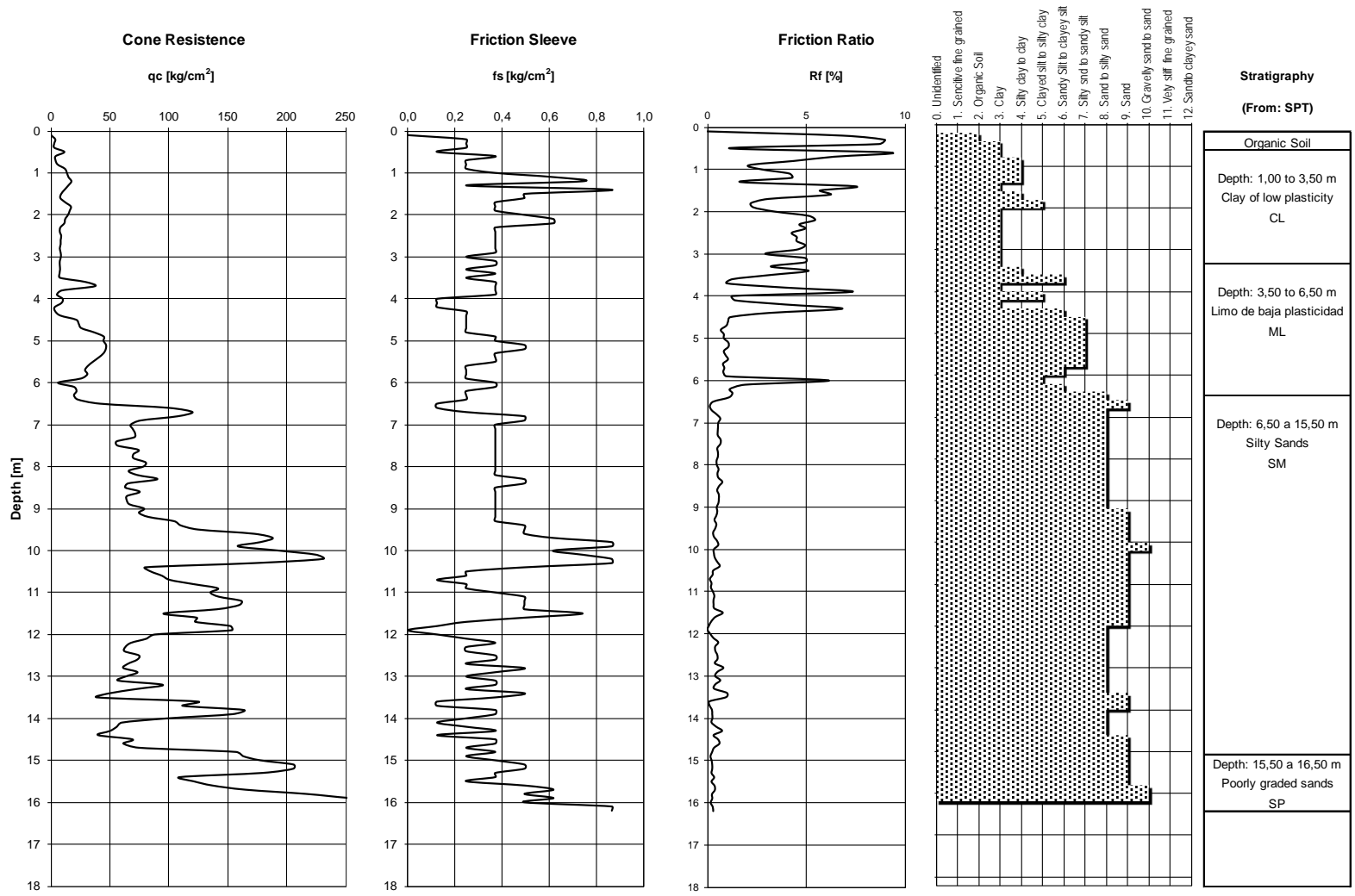

Figure 4. Typical result of CPT. Comparison between soil classification arisen from CPT and obtained in a simple borehole near to CPT.

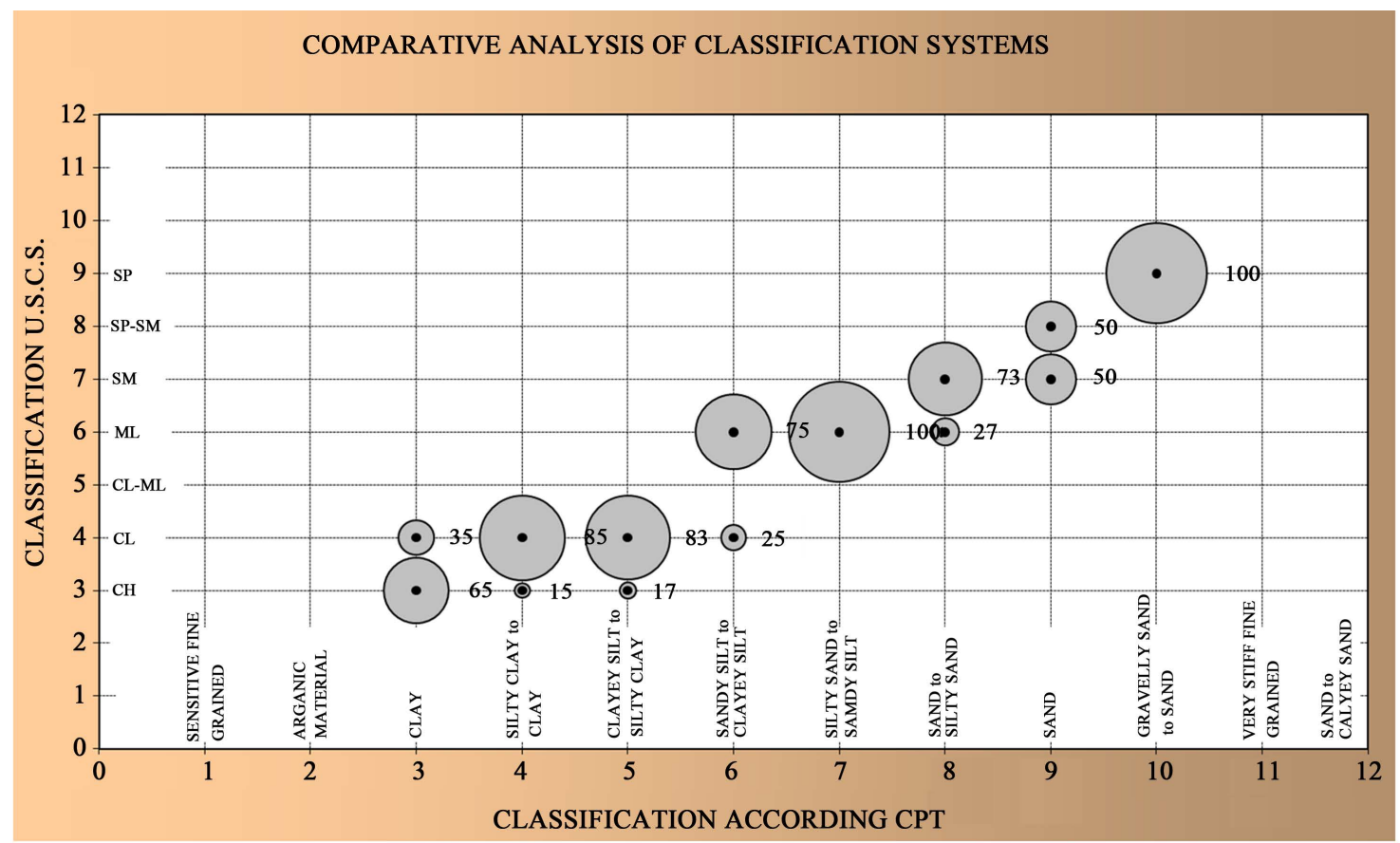

Figure 5. Comparison between soil classification obtained from CPT and the one obtained by means the USCS (Unified Soil Classification System) on samples obtained from near boreholes. 
3) Even though the universe of analyzed data (96 samples) is not of a great magnitude and should be enlarged, Figure 5 indicates in a preliminary way that for soils of the region there is a good correlation between [8] classification chart and the traditional USCS (Unified Soil Classification System).

\section{References}

[1] Wroth, C.P. (1984) The Interpretation of in Situ Soil Test. Géotechnique, 34, 449-489. http://dx.doi.org/10.1680/geot.1984.34.4.449

[2] Meigh, A.C. (1987) Cone Penetration Testing: Methods and Interpretation. Butterworths, London, 141 p.

[3] Lunne, T., Robertson, P.K. and Powell, J.J.M. (1997) Cone Penetration Testing in Geotechnical Practice. Blackie Academic \& Professional, London, 312 p.

[4] Begemann, H.K.S.P. (1963) The Use of Static Penetrometer in Holland. New Zealand Engineering, 18, 41-49.

[5] Schmertman, J.H. (1969) Dutch Friction-Cone Penetration Exploration of Research Area at Field 5. Vicksbug, Mississippi. US Army Waterways Experimental Station, Contract Report S-69-4.

[6] Searle, I.W. (1979) The Interpretation of Begemann Friction Jacket Cone Results to Give Soil Types and Design Parameters. Proceedings of 7th European Conference on Soil Mechanics and Foundation Engineering, Brighton, September 1979, 265-270.

[7] Douglas, B.J. and Olsen, R.S. (1981) Soil Classification Using Electric Cone Penetrometer. Proceedings of Conference on Cone Penetration Testing and Experience, St. Louis, 26-30 October 1981, 209-227.

[8] Robertson, P.K., Campanella, R.G., Gillespie, D. and Greig, J. (1986) Use of Piezometer Cone Data. Proceedings of American Society of Civil Engineers, ASCE, In-Situ 86 Specialty Conference, Blacksburg, 23-25 June 1986, 12631280.

[9] American Society for Testing of Materials (1987) Standard Test Method for Cone Penetration Testing: D3441-75T. Annual Book of ASTM Standards V.04.08., New York.

[10] Associação Brasileira de Normas Técnicas (1981) Ensaio de conepenetrometria: MB-3406. Rio de Janeiro. 